JOURNAL OF MIDWIFERY CARE :

VOL. 01 NO. 01, DESEMBER 2020

DOI: $10.34305 / \mathrm{jmc} . \mathrm{V} 1 \mathrm{i} 1.183$
Ciptaan disebarluaskan di bawah

Lisensi Creative Commons Atribusi-

NonKomersial-BerbagiSerupa 4.0

Internasional.

\title{
FAKTOR-FAKTOR YANG BERHUBUNGAN DENGAN ANEMIA PADA IBU HAMIL TRIMESTER I DI WILAYAH KERJA PUSKESMAS CIDAHU KABUPATEN KUNINGAN
}

\author{
${ }^{1}$ Tia Srimulyawati, ${ }^{2}$ Russiska, ${ }^{3}$ Fitry Miptahul Janah \\ ${ }^{1,2,3}$ Sekolah Tinggi Ilmu Kesehatan Kuningan
}

tiasrim89@gmail.com

\begin{abstract}
Abstrak
Anemia menjadi perhatian serius karena dampaknya pada ibu maupun janin berkontribusi terhadap kematian maternal. Penelitian ini bertujuan untuk mengetahui faktor-faktor yang berhubungan dengan anemia pada ibu hamil trimester I di Wilayah Kerja Puskesmas Cidahu Kabupaten Kuningan Tahun 2019. Jenis penelitian ini adalah analitik dengan rancangan crosssectional. Teknik pengambilan sampel menggunakan Total Sampling sebanyak 35 orang. Instrumen yang digunakan kuesioner dengan data penelitian bersifat primer dan sekunder, serta menggunakan analisis univariat dan bivariat dengan uji korelasi Rank Spearman. Hasil analisis univariat menunjukan jarak kehamilan berisiko (54,3\%), patuh mengkonsumsi tablet Fe $(54,3 \%)$, pendapatan rendah $(74,3 \%)$, ibu hamil trimester I tidak mengalami anemia $(68,6)$. Hasil analisis bivariat tidak terdapat hubungan jarak kehamilan dengan anemia pada ibu hamil trimester I dengan nilai $\rho$ value $(0,984>0,05)$ dan nilai $r=0,004$, terdapat hubungan antara konsumsi tablet Fe dengan anemia pada ibu hamil trimester I dengan nilai $\rho$ value $(0,030<0,05)$ dengan nilai $r=-$ 0,367, tidak terdapat hubungan pendapatan dengan anemia pada ibu hamil trimester I di Wilayah Kerja Puskesmas Cidahu Kabupaten Kuningan Tahun 2019 dengan nilai $\rho$ value $(0,135>0,05)$ dengan nilai $r=0,257$. Kesimpulan faktor yang berhubungan dengan anemia pada ibu hamil dalam penelitian ini adalah konsumsi tablet Fe namun faktor lain seperti jarak kehamilan dan pendapatan tidak terdapat hubungan dengan anemia pada ibu hamil trimester I.
\end{abstract}

Kata Kunci : Faktor-faktor, Anemia, Ibu hamil 
JOURNAL OF MIDWIFERY CARE :

VOL. 01 NO. 01, DESEMBER 2020

DOI: $10.34305 / \mathrm{jmc} . \mathrm{V} 1 \mathrm{i} 1.183$

\section{Pendahuluan}

Anemia adalah salah satu masalah kesehatan global yang umum dan tersebar luas serta mempengaruhi 56 juta wanita di seluruh dunia dan dua pertiga di antaranya berada di ASIA (Soh et al., 2015). Menurut World Health Organization (2012), 4\% kematian para ibu dinegara yang sedang berkembang berkaitan dengan anemia dalam kehamilan. WHO melaporkan bahwa prevalensi anemia pada ibu hamil di dunia berkisar rata-rata 41,8\%. Data Departemen Kesehatan (2016), prevalensi ibu hamil dengan anemia di Indonesia sebesar 37,1\%. Menurut Departemen Kesehatan (2016), di Indonesia frekuensi ibu hamil dengan anemia juga relatif tinggi yaitu 63,5\%, sedangkan di Jawa Barat angka kejadian anemia ibu hamil adalah $37,1 \%$. Data yang diperoleh dari Profil Dinas Kesehatan Kabupaten Kuningan, persentase anemia pada ibu hamil di Kabupaten Kuningan tahun 2017 yaitu 3,13\%. Besarnya angka kejadian anemia ibu hamil pada trimester I kehamilan adalah 20\%, trimester II sebesar $70 \%$, dan trimester III sebesar 70\%. Anemia dalam kehamilan dapat berdampak buruk
Ciptaan disebarluaskan di bawah

Lisensi Creative Commons Atribusi-

NonKomersial-BerbagiSerupa 4.0

Internasional.

terhadap mortalitas dan morbiditas ibu maupun janin. Hasil dari kehamilan dengan anemia diantaranya Intra Uterin Growth Retardation (IUGR), lahir prematur, Berat Bayi Lahir Rendah (BBLR), dan peningkatan risiko kematian neonatus. Efek anemia kehamilan pada ibu diantaranya sesak nafas, kelelahan, gangguan tidur, meningkatkan risiko perdarahan saat persalinan dan preeklamsia (Abu-Ouf \& Jan, 2015).

Faktor risiko yang mempengaruhi terjadinya anemia kehamilan diantaranya usia kehamilan, pendidikan ibu, pendapatan keluarga, jarak kehamilan, paritas, dan konsumsi Tablet Tambah Darah (TTD). Kebanyakan anemia disebabkan oleh defisiensi besi dan perdarahan akut, bahkan tidak jarang keduanya saling berinteraksi. Oleh karena itu, pemerintah melakukan program penanggulangan anemia pada ibu hamil yaitu dengan memberikan 90 tablet $\mathrm{Fe}$ kepada ibu hamil selama periode kehamilannya dengan tujuan menurunkan angka anemia ibu hamil. Cakupan pemberian tablet Fe di Jawa Barat tahun 2016 pada kunjungan pertama (F1) 
JOURNAL OF MIDWIFERY CARE :

VOL. 01 NO. 01, DESEMBER 2020

DOI: $10.34305 / \mathrm{jmc.v1i1.183}$

mencapai $102,3 \%$ dari perkiraan ibu hamil dan pada kunjungan ketiga (F3) terjadi penurunan poin menjadi 05,7\% (Dinas Kesehatan Jawa Barat, 2016). Sedangkan cakupan pemberian tablet Fe di Kabupaten Kuningan tahun 2017 mencapai 93\% (Dinas Kesehatan Kabupaten Kuningan, 2017).

Di Kabupaten Kuningan terdapat 38 Puskesmas, dan seluruhnya mempunyai cakupan pemberian 90 tablet tambah darah. Meskipun demikian, berdasarkan data yang diperoleh dari Dinas Kesehatan Kuningan bahwa jumlah ibu hamil pada tahun 2017 berjumlah 35.970 dan terdapat 2 Puskesmas dengan anemia ibu hamil yang masih tinggi yaitu Puskesmas Cidahu 72,81\% dan Puskesmas Manggari 58,90\% (Dinas Kesehatan Kabupaten Kuningan, 2017).

Dari studi pendahuluan yang dilakukan pada tanggal 25 Januari Tahun 2019 di Puskesmas Cidahu sebanyak 10 responden ibu hamil terdapat $1 \mathrm{ibu}$ hamil trimester III dengan kadar HB 11,7 gr\%, 8 responden ibu hamil trimester II dengan
Ciptaan disebarluaskan di bawah

Lisensi Creative Commons Atribusi-

NonKomersial-BerbagiSerupa 4.0

Internasional.

kadar HB 9,6 gr\% sampai 10 gr\% dan 1 responden ibu hamil trimester I dengan kadar HB 10,4 gr\%.

Tujuan penelitian ini adalah untuk mengetahui "Faktor-Faktor yang berhubungan dengan Anemia Pada Ibu Hamil Trimester I di Wilayah Kerja Puskesmas Cidahu Kabupaten Kuningan Tahun 2019”.

\section{Metode}

Penelitian ini menggunakan metode penelitian analitik dengan pendekatan crosssectional, menggunakan Total Sampling berjumlah 35 responden. Subjek penelitian adalah ibu hamil trimester I yang bersedia menandatangani lembar persetujuan yang diberikan setelah penjelasan (Informed Consent). Penelitian dilaksanakan di Wilayah Kerja Puskesmas Cidahu Kabupaten Kuningan pada bulan Mei - Juni tahun 2019. Metode analisis yang digunakan dalam penelitian ini menggunakan metode analisis Rank Spearman. 
JOURNAL OF MIDWIFERY CARE :

VOL. 01 NO. 01, DESEMBER 2020

DOI: $10.34305 / \mathrm{jmc} . \mathrm{V} 1 \mathrm{i} 1.183$
Ciptaan disebarluaskan di bawah

Lisensi Creative Commons Atribusi-

NonKomersial-BerbagiSerupa 4.0

Internasional.

\section{Hasil}

Tabel 1. Ganbaran faktor-faktor yang berhubungan dengan anemia pada ibu hamil

\begin{tabular}{lcc}
\hline \multicolumn{1}{c}{ Variabel } & Frekuensi (f) & Persentase (\%) \\
\hline Jarak Kehamilan & 19 & 54,3 \\
Berisiko & 16 & 45,7 \\
Tidak Berisiko & 19 & 54,3 \\
\hline Konsumsi Tablet Fe & 16 & 45,7 \\
Patuh & & \\
Tidak Patuh & 26 & 74,3 \\
\hline Pendapatan & 9 & 25,7 \\
Pendapatan rendah & & \\
Pendapatan tinggi & 11 & 31,4 \\
\hline Anemia & 24 & 68,6 \\
Anemia &
\end{tabular}

Sumber : Hasil Penelitian Tahun 2019

Berdasarkan Tabel 1.dapat diketahui bahwa dari 35 responden sebagian besar berisiko dengan jarak kehamilan sebanyak 19 Fe sebanyak 19 orang $(54,3 \%)$, dan memiliki pendapatan rendah sebanyak 26 orang $(74,3 \%)$. orang $(54,3 \%)$, patuh mengkonsumsi tablet

Tabel 2. Hubungan Faktor-faktor yang berhubungan dengan anemia pada ibu hamil

\begin{tabular}{|c|c|c|c|c|c|c|c|c|}
\hline \multirow{3}{*}{ Variabel } & \multicolumn{4}{|c|}{ Anemia } & \multirow{2}{*}{\multicolumn{2}{|c|}{ Total }} & \multirow{3}{*}{$\rho$ value } & \multirow{3}{*}{$r$} \\
\hline & \multicolumn{2}{|c|}{ Ya } & \multicolumn{2}{|c|}{ Tidak } & & & & \\
\hline & $\mathrm{f}$ & $\%$ & $\mathrm{f}$ & $\%$ & $\mathrm{f}$ & $\%$ & & \\
\hline \multicolumn{9}{|l|}{ Jarak kehamilan } \\
\hline Berisiko & 6 & 31,6 & 13 & 68,4 & 19 & 100 & \multirow{2}{*}{0,984} & \multirow{2}{*}{0,004} \\
\hline Tidak Berisiko & 5 & 31,2 & 11 & 68,8 & 16 & 100 & & \\
\hline \multicolumn{9}{|l|}{ Konsumsi Tablet Fe } \\
\hline Patuh & 3 & 15,8 & 16 & 84,2 & 19 & 100 & \multirow{2}{*}{0,030} & \multirow{2}{*}{$-0,367$} \\
\hline Tidak Patuh & 8 & 50,0 & 8 & 50,0 & 16 & 100 & & \\
\hline \multicolumn{9}{|l|}{ Pendapatan } \\
\hline Pendapatan Rendah & 10 & 38,5 & 16 & 61,5 & 26 & 100 & \multirow{2}{*}{0,135} & \multirow{2}{*}{0,257} \\
\hline Pendapatan Tinggi & 1 & 11,1 & 8 & 88,9 & 9 & 100 & & \\
\hline
\end{tabular}

Sumber : Hasil Penelitian Tahun 2019 
JOURNAL OF MIDWIFERY CARE :

VOL. 01 NO. 01, DESEMBER 2020

DOI: $10.34305 / \mathrm{jmc} . \mathrm{V} 1 \mathrm{i} 1.183$

Berdasarkan tabel 2 sebagian besar responden tidak mengalami anemia sebanyak 13 orang $(68,4 \%)$. Hasil uji statistik dengan menggunakan Spearman Rank diperoleh nilai $\rho$ value sebesar 0,984 dan nilai $r=0,004$ yang artinya tingkat hubungan jarak kehamilan dengan anemia sangat rendah. Hal yang sama juga terjadi pada variabel konsumsi tablet $\mathrm{Fe}$ dan pendapatan yang menunjukkan nilai $\rho$ value 0,030 dan nilai $r=-0,367$ pada konsumsi tablet Fe dan nilai $\rho$ value 0,135 dan nilai $r$ $=0,257$ pada variabel pendapatan yang artinya tingkat hubungan pendapatan dengan anemia rendah.

\section{Pembahasan}

Berdasarkan gambaran jarak kehamilan Ibu hamil trimester I dapat diketahui bahwa dari 35 responden sebagian besar memiliki jarak kehamilan berisiko yaitu sebanyak 19 orang $(54,3 \%)$. Hal ini sejalan dengan teori bahwa jarak kehamilan terlalu dekat yaitu kurang dari 2 tahun menjadi risiko karena sistem reproduksi belum kembali seperti keadaan semula sebelum hamil. Hal tersebut karena tubuh
Ciptaan disebarluaskan di bawah

Lisensi Creative Commons Atribusi-

NonKomersial-BerbagiSerupa 4.0

Internasional.

seorang ibu belum cukup untuk mengumpulkan cadangan nutrisi setelah melalui hamil pertama. Penentuan jarak kehamilan merupakan upaya untuk menetapkan atau memberi batasan antara kehamilan yang lalu dengan kehamilan yang akan datang (Mochtar, 2006).

Hasil penelitian ini sejalan dengan hasil penelitian yang dilakukan oleh Yunita (2015), yang menyatakan bahwa jarak kehamilan berisiko sebanyak 35 orang (56,5\%). Peneliti berasumsi bahwa jarak kehamilan yang diinginkan sebagian besar responden tidak selalu terpenuhi. Hal ini disebabkan oleh beberapa faktor seperti pengambilan keputusan yang tidak boleh dilakukan oleh istri, akan tetapi oleh anggota keluarga lainnya seperti suami atau ibu mertua. Jarak kehamilan berisiko tidak bisa diremehkan karena bisa berdampak pada kesehatan ibu dan bayi. Hal ini disebabkan karena tubuh ibu belum cukup untuk mengumpulkan cadangan nutrisi setelah kehamilan sebelumnya.

Berdasarkan Gambaran Kepatuhan Konsumsi Tablet Fe Ibu Hamil Trimester I dapat diketahui bahwa dari 35 responden 
JOURNAL OF MIDWIFERY CARE :

VOL. 01 NO. 01, DESEMBER 2020

DOI: $10.34305 / \mathrm{jmc.v1i1.183}$

sebagian besar memiliki ibu hamil patuh mengkonsumsi tablet Fe yaitu sebanyak 19 orang (54,3\%). Kepatuhan ibu hamil dalam mengkonsumsi tablet $\mathrm{Fe}$ sering menjadi masalah karena patuh sangat sulit untuk ditanamkan pada diri sendiri, apalagi untuk orang lain (Hernawati, 2013).

Hal ini sejalan dengan hasil penelitian Purnama (2014), yang menyatakan bahwa mengkonsumsi tablet $\mathrm{Fe}$ memang memberikan efek samping yang tidak menyenangkan seperti mual akibat rasa dan bau dari tablet Fe. Meskipun tablet Fe telah diberikan pada ibu hamil, belum dapat dipastikan apakah tablet tersebut dimakan oleh ibu hamil sehingga terjadi ketidakpatuhan dalam mengkonsumsi tablet Fe.

Hasil penelitian ini tidak sejalan dengan hasil penelitian yang dilakukan oleh Yanti \& Sulistianingsih (2016), yang menyatakan bahwa ibu hamil tidak patuh mengkonsumsi tablet Fe sebanyak 94 orang (56,0\%). Peneliti berasumsi bahwa kepatuhan ibu hamil dalam mengkonsumsi tablet Fe sangat dipengaruhi oleh diri ibu sendiri dalam menyadari pentingnya zat besi
Ciptaan disebarluaskan di bawah

Lisensi Creative Commons Atribusi-

NonKomersial-BerbagiSerupa 4.0

Internasional.

bagi dirinya dan bayinya terutama untuk kesehatannya agar selalu dalam kondisi baik, maka ia akan mengkonsumsi tablet Fe sesuai dengan yang dianjurkan.

Berdasarkan Gambaran Pendapatan Ibu Hamil Trimester I dapat diketahui bahwa dari 35 responden sebagian memiliki pendapatan rendah sebanyak 26 orang (74,3\%). Hal ini sesuai dengan teori menurut Marmi \& Fatmawati (2011), bahwa tingkat pendapatan terbukti sangat berpengaruh terhadap kondisi kesehatan fisik dan psikologis ibu hamil. Pada ibu hamil dengan pendapatan tinggi otomatis akan mendapatkan kesejahteraan fisik dan psikologi yang baik. Status gizi pun akan meningkat karena nutrisi yang didapatkan berkualitas.

Hasil penelitian sejalan dengan hasil penelitian yang dilakukan oleh Ristica (2013), yang menyatakan bahwa ibu hamil dengan pendapatan rendah sebanyak 132 orang $(68,9 \%)$. Hal ini disebabkan karena pendapatan rendah menyebabkan tidak terpenuhinya kebutuhan gizi ibu hamil yang dikonsumsi sehari-harinya. 
JOURNAL OF MIDWIFERY CARE :

VOL. 01 NO. 01, DESEMBER 2020

DOI: $10.34305 / \mathrm{jmc} . \mathrm{V} 1 \mathrm{i} 1.183$

Peneliti berasumsi bahwa rata-rata hanya kepala keluarga yang bekerja. Seorang istri hanya bisa mengharapkan uang dari suami untuk keperluan rumah tangga. Dengan pendapatan keluarga yang rendah, diperkirakan tidak cukup untuk membeli makanan yang dapat memenuhi kebutuhan $\mathrm{Fe}$ dari protein hewani untuk ibu hamil karena sudah habis untuk membeli kebutuhan keluarga yang lain seperti kebutuhan sandang dan pangan.

Hasil uji korelasi hubungan jarak kehamilan dengan anemia pada ibu hamil trimester I menggunakan Spearman Rank didapatkan bahwa berdasarkan arahnya ( $\rho$ value 0,984>0,05), korelasi antara jarak kehamilan dengan anemia ibu hamil trimester I adalah positif, artinya apabila tingkat jarak kehamilan berisiko $\leq 2$ tahun meningkat maka tingkat anemia ibu hamil pun meningkat. Besarnya korelasi secara statistik termasuk dalam tingkat sangat rendah $(r=0,004)$.

Hal ini sesuai dengan teori menurut Astriana (2017), yang menyatakan bahwa proporsi kematian terbanyak terjadi pada ibu dengan prioritas 1-3 anak dan jika dilihat
Ciptaan disebarluaskan di bawah

Lisensi Creative Commons Atribusi-

NonKomersial-BerbagiSerupa 4.0

Internasional.

menurut jarak kehamilan yang terlalu dekat menyebabkan ibu mempunyai waktu singkat untuk memulihkan kondisi rahimnya agar bisa kembali ke kondisi sebelumnya. Ibu hamil dengan jarak terlalu dekat beresiko terjadi anemia dalam kehamilan, karena cadangan zat besi ibu belum pulih, akhirnya berkurang untuk keperluan janin yang dikandungnya.

Kemudian hasil penelitian Anggraini (2018) juga menunjukkan bahwa dari 40 responden yang diteliti mayoritas memiliki ibu hamil berisiko mengalami anemia. Hal ini disebabkan karena tubuh seorang ibu belum cukup untuk mengumpulkan cadangan nutrisi setelah melalui kehamilan pertama. Hasil penelitian ini sejalan dengan hasil penelitian Sepduwiana \& Sutrianingsih (2017), yang menyatakan bahwa tidak ada hubungan jarak kehamilan dengan kejadian anemia pada ibu hamil. Hal ini disebabkan karena lebih banyak responden yang memiliki jarak kehamilan lebih dari 2 tahun untuk memulihkan organ reproduksinya.

Berdasarkan hasil penelitian sebagian besar responden dengan jarak kehamilan berisiko tidak mengalami 
JOURNAL OF MIDWIFERY CARE :

VOL. 01 NO. 01, DESEMBER 2020

DOI: $10.34305 / \mathrm{jmc.v1i1.183}$

anemia, peneliti mendapat motif dari keinginan memiliki anak kembali sebagian disebabkan karena pengalaman kehamilan yang lalu yang kurang beruntung (abortus) sehingga pada kehamilan sekarang ibu hamil sangat selektif dan menggali banyak informasi tentang bahaya yang bisa saja terjadi pada kehamilan awal. Hal lain yang peneliti dapatkan dilapangan adalah sebagian besar ibu hamil sudah melaksanakan ANC Terpadu yang diadakan oleh Puskesmas untuk mengurangi kejadian anemia dan tanda-tanda bahaya yang terjadi di Trimester I.

\section{Hasil uji korelasi hubungan} kepatuhan konsumsi tablet fe dengan anemia pada ibu hamil trimester I didapatkan bahwa $\rho$ value $0,030<0,05$. Berdasarkan arahnya, korelasi antara konsumsi tablet $\mathrm{Fe}$ dengan anemia ibu hamil trimester I adalah negatif, artinya apabila kepatuhan mengkonsumsi tablet Fe meningkat maka kejadian anemia pada ibu hamil menurun. Besarnya korelasi secara statistic termasuk rendah $(r=-0,367)$.

Menurut teori Prawirohardjo (2016), yang menyatakan bahwa tingginya kejadian anemia berakar pada asupan yang kurang
Ciptaan disebarluaskan di bawah

Lisensi Creative Commons Atribusi-

NonKomersial-BerbagiSerupa 4.0

Internasional.

adekuat, rendahnya mengkonsumsi tablet $\mathrm{Fe}$, kesediaan hayati yang rendah, dan angka kecacingan yang masih tinggi. Sehingga intake makanan dan ketaatan mengkonsumsi tablet $\mathrm{Fe}$ merupakan salah satu faktor penyebab masih tingginya angka kejadian anemia pada ibu hamil.

Berdasarkan hasil penelitian sebagian besar responden patuh mengkonsumsi tablet Fe tidak mengalami anemia, peneliti berasumsi bahwa ibu hamil yang patuh mengkonsumsi tablet $\mathrm{Fe}$ disebabkan karena tingkat pengetahuan yang cukup sehingga ibu hamil memiliki kesadaran untuk terus mengkonsumsi tablet Fe meskipun ada anggapan negatif mengenai suplementasi besi di masyarakat merupakan salah satu hal yang menyebabkan efek samping perasaan mual dan bosan ketika minum secara rutin.

Hasil uji korelasi hubungan pendapatan dengan anemia pada ibu hamil trimester I didapatkan bahwa berdasarkan arahnya, pendapatan dengan anemia ibu hamil trimester I adalah positif( $\rho$ value 0,135 $<0,05)$, artinya apabila pendapatan tinggi maka kejadian anemia pada ibu hamil 
JOURNAL OF MIDWIFERY CARE :

VOL. 01 NO. 01, DESEMBER 2020

DOI: $10.34305 / \mathrm{jmc.v1i1.183}$

meningkat. Besarnya korelasi secara statistik termasuk rendah $(\mathrm{r}=0,257)$.

Berdasarkan hasil penelitian Yanti \& Sulistianingsih (2016) diperoleh bahwa mayoritas memiliki pendapatan dalam kategori rendah dan mengalami anemia. Hal ini disebabkan karena sumber makanan yang terbanyak mengandung zat besi adalah yang berasal dari protein hewani yang harganya cukup mahal. Mahalnya bahan makanan tersebut memungkinkan tidak dapat dijangkau masyarakat dengan pendapatan rendah.

Berdasarkan hasil penelitian sebagian besar responden memiliki pendapatan rendah tidak mengalami anemia, peneliti berasumsi bahwa pendapatan dapat berpengaruh terhadap kejadian anemia pada ibu hamil. Hal tersebut terjadi bukan hanya karena penghasilan keluarga, tetapi ada faktor lain seperti kesadaran, pengetahuan, kepatuhan mengkonsumsi tablet Fe, paritas, pendidikan. Hal ini sejalan dengan penelitian Istiqomah et al. (2013), yang memaparkan faktor-faktor yang berkaitan dengan kejadian anemia pada ibu hamil.
Ciptaan disebarluaskan di bawah

Lisensi Creative Commons Atribusi-

NonKomersial-BerbagiSerupa 4.0

Internasional.

\section{Kesimpulan}

Faktor yang berhubungan dengan anemia pada ibu hamil adalah konsumsi tablet Fe namun pada faktor lain seperti jarak kehamilan dan pendapatan tidak terdapat hubungan dengan anemia pada ibu hamil trimester I.

\section{Saran}

Ibu hamil disarankan mengkonsumsi makanan yang bergizi dan rutin berolahraga, memeriksakan kehamilan secara rutin (minimal 4 kali selama kehamilan) karena dapat mendeteksi dini dan meminimalisir terjadinya komplikasi kehamilan seperti anemia dalam kehamilan

\section{Daftar Pustaka}

Abu-Ouf, N. M., \& Jan, M. M. (2015). The impact of maternal iron deficiency and iron deficiency anemia on child's health. Saudi Medical Journal, 36(2), 146.

Anggraini, P. D. (2018). Faktor-faktor yang berhubungan dengan kejadian anemia pada ibu hamil di wilayah kerja Puskesmas Tanjung Pinang tahun 2018. Jurnal Kebidanan, 7(15), 33-38.

Astriana, W. (2017). Kejadian anemia pada 
JOURNAL OF MIDWIFERY CARE :

VOL. 01 NO. 01, DESEMBER 2020

DOI: $10.34305 / \mathrm{jmc.v1i1.183}$

ibu hamil ditinjau dari paritas dan usia. Aisyah: Jurnal Ilmu Kesehatan, 2(2), 217394.

Departemen Kesehatan. (2016a). Riset Kesehatan Dasar Tahun 2016.

Departemen Kesehatan. (2016b). Sistem Kesehatan Nasional 2016.

Dinas Kesehatan Jawa Barat. (2016). Profil Kesehatan Provinsi Jawa Barat.

Dinas Kesehatan Kabupaten Kuningan. (2017). Profil Kesehatan Kabupaten Kuningan.

Hernawati, J. S. (2013). Hubungan kepatuhan konsumsi tablet tambah darah dengan status anemia ibu hamil di desa kotaraja kecamatan sikur. Media Bina Ilmiah, 7(1), 1-6.

Istiqomah, G. A. N., Rinayati, R., Zulaika, C., \& Wahyudi, D. (2013). Hubungan Antara Kadar Hemoglobin Dengan Prestasi Belajar Mahasiswa Program Studi Diii Kebidanan Stikes Widya Husada Semarang Tahun 2012. Prosiding SNST Fakultas Teknik, 1(1).

Marmi, S. A., \& Fatmawati, E. (2011). Asuhan Kebidanan Patologi. Yogyakarta: Pustaka Pelajar.

Mochtar, R. (2006). Sinopsis Obstetri. EGC.

Prawirohardjo, S. (2016). Ilmu Kebidanan. Yayasan Bina Pustaka.
Ciptaan disebarluaskan di bawah

Lisensi Creative Commons Atribusi-

NonKomersial-BerbagiSerupa 4.0

Internasional.

Purnama, D. I. (2014). 100 Hal Penting Yang Wajib Diketahui Bumil. PT Kawan Pustaka, Jakarta Selatan.

Ristica, O. D. (2013). Faktor Risiko Kejadian Anemia Pada Ibu Hamil. Jurnal Kesehatan Komunitas, 2(2), 78 82.

Sepduwiana, H., \& Sutrianingsih, R. N. S. (2017). Hubungan Jarak Kehamilan dan Kepatuhan Mengkonsusi Tablet Fe dengan Kejadian Anemia pada Ibu Hamil di Wilayah Kerja Puskesmas Rambah Samo 1. Jurnal Martenity and Neonatal, 2(4).

Soh, K. L., Malaysia, U. P., Malaysia, U. P., Malaysia, U. P., Malaysia, U. P., Mewah, P., \& Malaysia, U. P. (2015). Anemia among antenatal mother in urban Malaysia. Journal of Biosciences and Medicines, 3(03), 6.

World Health Organization. (2012). Maternal Mortality.

Yanti, D., \& Sulistianingsih, A. (2016). Keisnawati. 2015. Faktor-faktor terjadinya anemia pada ibu primigravida di wilayah kerja puskesmas Pringsewu Lampung. Jurnal Keperawatan, 6(2), 79-87.

Yunita, S. (2015). Faktor-Faktor yang Berhubungan dengan Kejadian Anemia Pada Ibu Hamil Trimester III di Puskesmas Umbulharjo II. 